\title{
ORBITAL FLOOR BLOW-OUT FRACTURES: ULTRASONOGRAPHY, POSTOPERATIVE COMPLICATIONS AND REHABILITATION
}

\author{
Daiva Imbrasienė 1, 2, Alvyra Veronika Valasevičienė', \\ Akvilè Daveckaité ${ }^{3}$, Rima Kregždytë $^{4}$ \\ Eye Hospital of Lithuanian University of Health Sciences Kauno Klinikos ${ }^{1}$ \\ Lithuanian Academy of Physical Education ${ }^{2}$ \\ Lithuanian University of Health Sciences, Medical Academy ${ }^{3}$ \\ Lithuanian University of Health Sciences, Institute of Neuroscience ${ }^{4}$
}

\section{SUMMARY}

The aim of this retrospective study was to analyze indications and the efficiency of post-operative rehabilitation in patients with orbital floor blow-out fractures.

The selected patients were with orbital floor blow-out fractures and post-operative rehabilitation; eight case records were traced. The symptoms of the eyes (eye position and movements, coordimetry, ultrasonography) were noted before and after surgical correction and rehabilitation treatment. The data were statistically analyzed using a computer software package, SPSS version 16.0. A value of $\mathrm{p}<0.05$ was considered as statistically significant.

All eight $(100 \%)$ patients were men. The average age was $19.88 \pm 8.25$ years $(14-34$ years). The most common complaint was diplopia, it was in eight (100\%) patients' numb of affected face side was in two (28.6\%), vertigo in one $(12.5 \%)$, nausea in one $(12.5 \%)$ patient. Post-operative complications were: diplopia - eight $(100 \%)$ patients, postoperative scar - three $(37.5 \%)$, eyelid swelling - four $(50 \%)$, haematoma - one $(12.5 \%)$ patient. After rehabilitation post-operative symptoms (postoperative scar, eyelid swelling, haematoma) decreased significantly $(p<0.05)$. Insignificant diplopia was left in seven $(87.5 \%)(p>0.05)$ patients, but it did not disturb their general activities. Patients were not treated surgically, neither they got correction with prismatic spectacles after rehabilitation. One (12.5\%) patient was under supervision. Before rehabilitation ultrasonography was done for five $(62.5 \%)$ patients. Ultrasonography was repeated only for one (12.5\%) patient after rehabilitation. Coordimetry was done for all patients while they were being treated in order to find out the efficiency of rehabilitation.

Rehabilitation can be recommended to patients with post-operative complications such as diplopia, swelling, post-operative scar. Treatment effect should be objectified by ultrasonography.

Keywords: rehabilitation, orbital floor fracture, postoperative complications, ultrasonography.

\section{INTRODUCTION}

Seven bones conjoin to form the orbit which protects, supports, and maximizes the function of the eye. The orbital plate of the zygoma joins the orbital plate of the maxilla and the orbital plate of the palatine bones to form the floor. The thin orbital floor and the lamina papyracea medially and inferiorly is the weakest part of the orbit [1].

The term "blow-out" fracture was used to describe inferior rectus entrapment with decreased ocular motility in the setting of an orbital floor fracture in 1957 by B. Smith and W. F. J. Regan [2]. This type of fractures is mostly caused by increased hydraulic pressure with direct compression force or transmitted buckling force through the orbit rim [3].

The orbital floor fracture may cause an entrapment of orbital contents in maxillary sinus [1]. When inferior rectus muscle is entraped, tethering and restriction of gaze and diplopia may result $[1,3,4,5]$. Enophthalmos, diplopia resulting from extraocular muscle dysfunction, and infraorbital nerve hypesthesia are the most common complications $[4,6]$. Demographic analysis of the highest-risk groups reveals that eye injury rates are highest among young males [1, 4, 5, 6, 7]

It is important to choose the best imaging method while assessing traumatic orbital injuries. Radiographic examination of the orbits is rarely performed nowadays. The disadvantages of magnetic resonance imaging (MRI) may be the difficulty to perform it emergently; it is contraindicated if there is a possibility of a metallic intraorbital foreign body. Computed tomography (CT) is considered to be the most valuable diagnostic method for evaluating orbital trauma. The best protocol is to obtain thin-section axial CT scans at first, then to perform multiplanar reformation [8].

Ocular ultrasonography became more common in the 1990 s and now is one of the helpful radiological techniques to evaluate orbital trauma [9]. It is possible to detect bone fractures, stubs, tissue entrapment, hemorrhage, emphysema [10]. According to W. D. Adeyemo and O. A. Akadiri, the sensitivity and specificity of ultrasound in detecting orbital fractures is $56-100 \%$ and $85-100 \%$. Evidence justifies the use of diagnostic ultrasonography in maxillofacial fractures, especially fractures involving the nasal bone, orbital walls, anterior maxillary wall and zygomatic complex. The sensitivity and specificity of ocular ultrasonography is generally comparable with CT [11].

Blow-out fracture is indication for immediate surgical repair. Various studies suggest surgery within two weeks after trauma in order to lower very disappointing postoperative complications, such as diplopia, enophthalmos and infraorbital nerve dysfunction that may occur although the surgical technique was executed properly $[3,4,6]$.

Postoperative complications play a role in patients' lives, mainly because it is a problem of young employable persons. Postoperative facial appearance changes 
stimulate social problems. Diplopia disturbs motion in space, near vision, determines driving difficulties, difficulties at work, interferes with social function [3, 4, 6]. Diplopia, for example, can be corrected by prisms or even eye muscle surgery may be required to address this problem with repositioning of the extraocular muscles to allow for orthophoric fixation of images.

A possibility of rehabilitation treatment should be considered if diplopia, postoperative scar, intraorbital haematoma, edema, swelling occur. Rehabilitation treatment is often chosen when all conventional treatment methods have failed to produce adequate clinical results. But even small improvement gives great benefit: scars mitigate, improve extraoculars muscles motility, pain relief, decrease duration of treatment, reduce expenses, individual welfare [12, 13, 14].

As the main goal of treatment is to maintain the best possible physiologic function and aesthetic appearance to the area of injury, the aim of this study was to evaluate indications and the efficiency of postoperative rehabilitation treatment and the value of ultrasonograhy in patients with orbital floor blow-out fractures.

\section{MATERIAL AND METHODS}

Eight medical case records were examined retrospectively. The selected patients were with diplopia who underwent an operation and postoperative rehabilitation after orbital blow-out fractures treatment at the Department of Ophthalmology at Kaunas University of Medicine from 2009 to 2010. Patients who had other type orbital fractures or other coexisting facial fractures were excluded from this study. Demographic data, complaints after trauma, clinical and ultasonography findings, surgical timing, postoperative complications, rehabilitation course and outcome were investigated.

Statistical analysis was performed using computer software package SPSS version 16.0. The chi-square test and McNemar criteria were used for statistical analyses. A value of $p<0.05$ was considered as statistically significant.

At the early postoperative period local procedures of low frequency pulsed electromagnetic field (PEMF) therapy were applied. PEMF therapy procedures were performed with „Polius-1“ device and applied directly to the site of injury aiming at helping bone unification, the reduction of pain, edema, and inflammation, and increasing blood circulation. For the first two days procedures of $10 \mathrm{mT}$ intensity and 10 minutes duration were prescribed. Later the intensity was increased to 17-20 mT and carried on for 10-15 minutes.

Resorptional ionophoresis with Lydasa (parameters: $32 \mathrm{~V}$, length 15-20 minutes, number of procedures 12-15) and ultrasound therapy with steroids unguent (hydrocortisone phonophoresis) (parameters: $0.4 \mathrm{~W} / \mathrm{cm}^{2}$ continuously for 6 minutes, 8-12 sessions) were prescribed for scar, edema and extraocular muscles motility improvement.

All these procedures were combined with eye movement exercises. Coordimetry and ultrasonography were prescribed to evaluate the efficiency of rehabilitation treatment.

\section{RESULTS}

All eight (100\%) patients were men. Their mean age was $19.88 \pm 8.25$ years $(14-34$ years). The mean time from trauma to surgery was 10 days (1-30 days). The most common complaint after trauma was diplopia, it was in eight $(100 \%)$ patients, numb of affected face side was in two $(28.6 \%)$, vertigo in one $(12.5 \%)$, nausea in one $(12.5 \%)$ patient. Postoperative complications were: diplopia - eight $(100 \%)$ patients, postoperative scar three $(37.5 \%)$, eyelid swelling - $4(50 \%)$, haematoma one (12.5\%). Rehabilitation was started in 39 days after operation (1 day -6 months). After rehabilitation postoperative scar, eyelid swelling, haematoma decreased for all patients $(p<0.05)$ (Table). Only slight diplopia was left in seven (87.5\%) patients, it had no influence in their general activities $(p>0.05)$. There was no need of strabismus correction with prismatic spectacles or strabismus correction surgery after rehabilitation. One $(12.5 \%)$ patient still was under supervision. Before rehabilitation ultrasonography was done for five (62.5\%) patients. Extraocular muscles were examined for three $(37.5 \%)$ patients, intumescence of extraocular muscles was found in two $(25 \%)$ patients, retrobulbar haematoma was in one $(12,5 \%)$ patient. Ultrasonography was repeated only for one (12.5\%) patient after rehabilitation and improvement of extraocular muscles and haematoma was observed. Coordimetry was being done routinely for all patients while they were being treated in order to find out the efficiency of rehabilitation. After rehabilitation improvement in swelling, postoperative scar and intraorbital haematoma was found.

Table. Postoperative complications before and after rehabilitation

\begin{tabular}{|c|c|c|c|}
\hline Symptom & Before rehabilitation & After rehabilitation & McNemar criterion \\
\hline Postoperative scar & $3(37.5 \%)$ & 0 & $\mathrm{p}<0.05$ \\
\hline Eyelid swelling & $4(50 \%)$ & 0 & $\mathrm{p}<0.05$ \\
\hline Haematoma & $1(12.5 \%)$ & 0 & $\mathrm{p}<0.05$ \\
\hline
\end{tabular}


Orbital floor blow-out fractures is a problem of young employable people. In our study all eight patients were young men and their mean age was $19.88 \pm 8.25$ years (14-34 years). In their study $\mathrm{H}$. Yano et al. [5] examined 22 cases, 18 patients were males and 4 were females, their mean age was 14.3 years (ranging from 6 to 45 years) [5]. M. Brucoli et al. [6] examined 40 patients (29 men and 11 women) who underwent surgical repair of isolated orbital blow-out fracture. Their mean age was 47.7 years (range $30-60$ years).

The main postoperative complication that we found was diplopia. It occurred in all eight patients. A lot of studies present diplopia as one of the most common complications $[4,5,6,7]$. Yano et al. maintain that diplopia may result from deformity of the orbit (when causing positional changes of the muscles), adhesive impingement of the content (disturbing ocular excursion) and impairment of the contracting muscle (resulting from neurogenic or myogenic palsy). On the one hand, living organisms have the adaptability to compensate for functional defects, so diplopia may be ameliorated with time; on the other hand, diplopia is self-limiting in the majority of cases because it is usually caused by intraorbital edema and resolves with resolution of swelling $[5,7]$.

M. Brucoli et al. [6] observed that diplopia was present in $42.5 \%$ of the 40 patients at the mean followup of 39 months and did not develop or become worse in any patients after surgery [6]. According to $\mathrm{H}$. Yano et al. [5], early rehabilitation is important in patients with missing rectus because infraduction restriction initially remains serious despite the removal of mechanical interference [5]. In our study, after rehabilitation treatment insignificant diplopia was left in seven patients.
The rehabilitation effect was evaluated by coordimetry (Figure). Patients were satisfied by treatment results, diplopia had no significant effect in their lives. There was no need of correction with prismatic spectacles or stabismus surgery, patients were able to read from close distance, drive a car, they had no difficulties in space perception. Since diplopia is a significant complication (the most common one and causes a lot of disturbances in patients' daily life), early postoperative rehabilitation is the tool that helps to achieve the main aim of treatment: to restore the function of the external eye muscles and improve patients' life quality.

Coordimetry was used to evaluate rehabilitation effect objectively. It has to be pointed out that coordimetry is a subjective method and it strongly depends on patients' head position, concentration, correct answers. So there is a need for objective treatment evaluation. Ultrasonography allows to evaluate extraocular muscles, retrobulbaropticnerve, orbital soft tissues, vasculature and periorbital regions [15]. In our study, ultrasonography was done for five patients with postoperative complications. Such findings as intumescence of extraocular muscles, retrobulbar haematoma proved rehabilitation treatment. After rehabilitation, ultrasonography was repeated only for one patient and improvement was found. We think ultrasonography should be used more in assessing an efficiency of treatment because of these advantages (as well as disadvantages of CT and MRI though): the possibility to use this method at postoperative period for many times, it is harmless and quite cheap [10,15].

There are no data about prospective studies that compare postoperative complications with or without rehabilitation. So rehabilitation is started in early postoperative period in case to get individual and socioeconomic welfare.

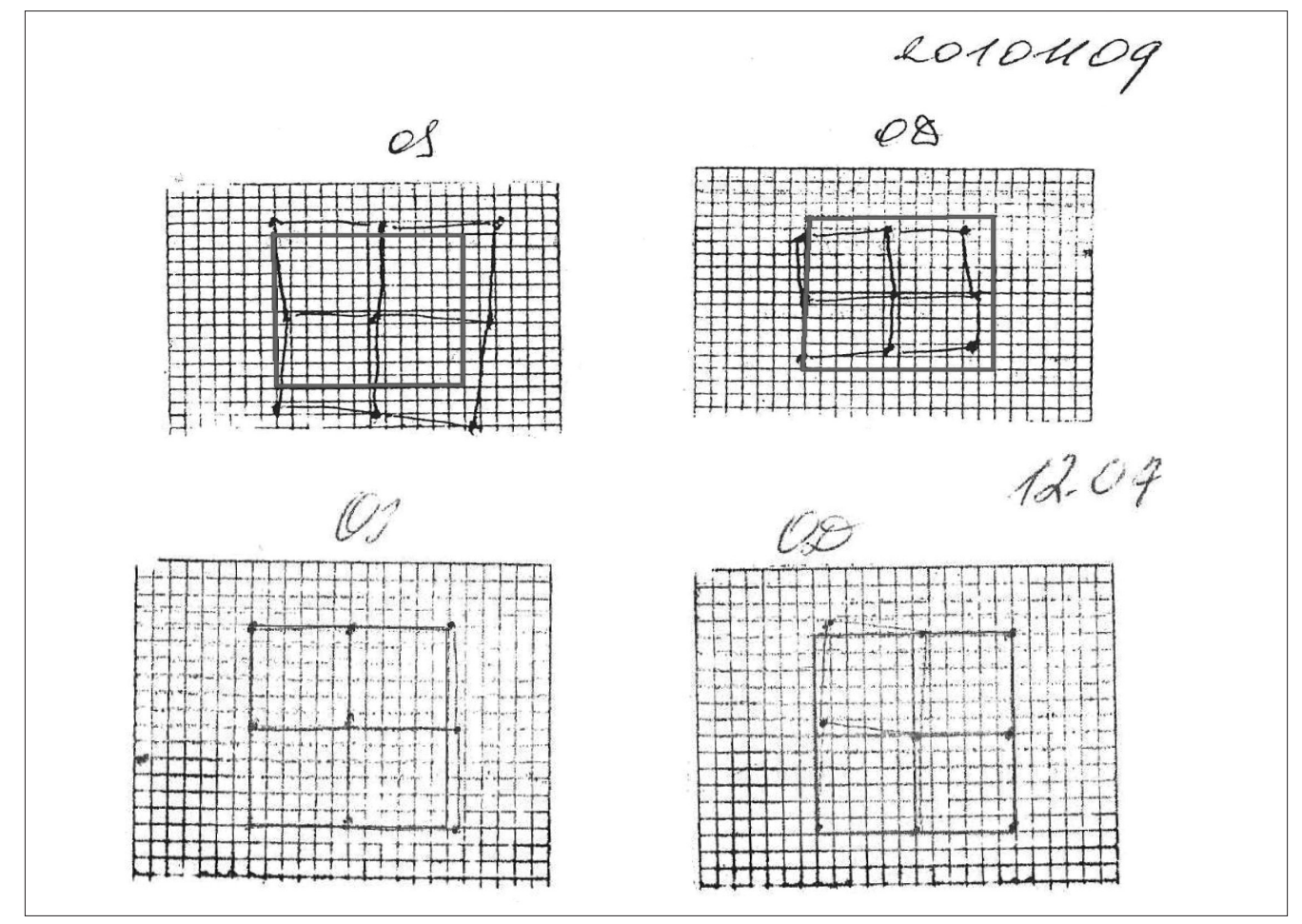

Note. Red line signs means normal. After surgery (2010.11.09) significant diplopia occurred. After rehabilitation (12.07) insignificant diplopia remained when patient looked down.

Figure. Coordimetry before and after rehabilitation 


\title{
CONCLUSIONS
}

Orbital floor blow-out fracture is a problem of young patients so it needs to be solved properly. The main complaint after trauma was diplopia and it remained after operation. Ultrasonography allows evaluating signs of fracture, indicating treatment method, the purpose of rehabilitation, so the treatment effect should be objectived by ultrasonography. Rehabilitation can be recommended for patients with postoperative compications such as diplopia, swelling, postoperative scar.

\section{REFERENCES}

1. Kummoona, R. (2009). Management of injuries of the orbital skeleton. The Journal of Craniofacial Surgery, 20 (3), 762-767.

2. Smith, B., Regan, W. F. Jr. (1957). Blow-out fracture of the orbit: Mechanism and correction of internal orbital fracture. American Journal of Ophthalmology, 44 (6), 733-739.

3. Gonzalez, M., Durairaj, V. (2010). Indirect Orbital Fractures: A meta-analysis. Middle East African Journal of Ophthalmology, 17 (2), 138-141.

4. Burnstine, M. A. (2002). Clinical recommendations for repair of isolated orbital floor fractures: An evidence-based analysis. Ophthalmology, 109 (7), 1207-1210.

5. Yano, H., Suzuki, Y., Yoshimoto, H., Mimasu, R., Hirano, A. (2010). Linear-type orbital floor fracture with or without muscle involvement. The Journal of Craniofacial Surgery, 21 (4), 1072-1078.

6. Brucoli, M., Arcuri, F., Cavenaghi, R., Benech, A. (2011). Analysis of complications after surgical repair of orbital fractures. The Journal of Craniofacial Surgery, 22 (4), 1387-1390.

7. Ellis, E., Tan, Y. (2003). Assessment of internal orbital reconstructions for pure blowout fractures: Cranial bone grafts versus titanium mesh. International Journal of Oral and Maxillofacial Surgery, $61,442-453$.
8. Kubal, W. S. (2008). Aging of orbital trauma. Radiographics, 28 (6) 1729-1739.

9. Blaivas, M. (2000). Bedside emergency department ultrasonography in the evaluation of ocular pathology. Academic Emergency Medicine, 7 (8), 947-950.

10. Imbrasienè, D. (2011). Akiduobés ultragarsiniai tyrimai. Klaipèda: Druska.

11. Adeyemo, W. L., Akadiri, O. A. (2011). A systematic review of the diagnostic role of ultrasonography in maxillofacial fractures. International Journal of Oral and Maxillofacial Surgery, 40 (7), 655-661.

12. Markov, M. S. (2007). Expanding use of pulsed electromagnetic field therapies. Electromagnetic Biology and Medicine, 26, 257-274.

13. Weintraub, M. I. (2004). Magnetotherapy: Historical background with a stimulating future. Critical Review in Physical and Rehabilitation Medicine, 16 (2), 95-108.

14. Сердюк, В. В. (2004). Магнитотерапия. Стоматология и целюстно-лицевая хирургия. Киев. С. 152-161.

15. DiBernardo, C. W, Greenberg, E. F. (2006). Ophthalmic Ultrasound: A Diagnostic Atlas. New York: Thieme.

\section{AKIDUOBE்S APATINĖS SIENELE்S LŪŽIAI: ULTRAGARSINIS TYRIMAS, POOPERACINÉS KOMPLIKACIJOS IR REABILITACIJA}

\author{
Daiva Imbrasienè 1, 2, Alvyra Veronika Valasevičienë1, \\ Akvilè Daveckaité ${ }^{3}$, Rima Kregždytė ${ }^{4}$ \\ Lietuvos sveikatos mokslų universiteto ligoninè Viešoji istaiga Kauno klinikos, Akių ligu klinika ${ }^{1}$ \\ Lietuvos kūno kultūros akademija² \\ Lietuvos sveikatos moksly universitetas, Medicinos akademija ${ }^{3}$ \\ Lietuvos sveikatos moksly universitetas, Neuromoksly institutas ${ }^{4}$
}

\section{SANTRAUKA}

Tyrimo tikslas - įvertinti reabilitacinio gydymo galimybes po komplikuoto akiduobės apatinės sienelės lūžio chirurginio gydymo.

Atlikta retrospektyvi aštuonių Akių ligų klinikos ligonių, gydytų 2009-2010 metais, ligos istorijų analizè. Ligonių atrankos kriterijai: apatinės akiduobės sienelès lūžio chirurginẻ korekcija ir dèl pooperacinių komplikacijų taikytas reabilitacinis gydymas. Ivertinti akiụ simptomai (akies padètis ir judesiai, koordimetrija, ultragarsinis tyrimas prieš chirurgini bei reabilitacinį gydymą ir po jų. Atlikta statistinè duomenų analizė SPSS 16.0 duomenų paketu, skirtumai vertinti kaip statistiškai reikšmingi, kai $p<0,05$.

Vidutinis ligonių amžius - 19,88 \pm 8,25 metų (nuo 14 iki 34 m.). Visi aštuoni (100\%) ligoniai buvo vyrai. Dažniausi nusiskundimai: dvejinimusi skundèsi aštuoni ligoniai $(100 \%)$, pažeistos pusės veido nutirpimu - du $(28,6 \%)$, galvos svaigimu - vienas $(12,5 \%)$, pykinimu - vienas $(12,5 \%)$. Nusiskundimai po operacijos: dvejinimasis diagnozuotas aštuoniems (100\%) ligoniams, randas - trims $(37,5 \%)$, voko patinimas - keturiems $(50 \%)$, hematoma - vienam $(12,5 \%)$. Ǐslikęs nedidelis dvejinimasis netrukdè septynių $(87,5 \%)$ $(p>0,05)$ ligoniu kasdienei veiklai, vienas $(12,5 \%)$ ligonis dar buvo sekamas. Kiti nusiskundimai sumažèjo statistiškai patikimai $(p<0,05)$ : sušvelnèjo rando formavimasis, voko patinimas, hematoma. Po reabilitacinio gydymo nè vienam iš ligonių netaikyta žvairumo koregavimo operacija ar prizminiai akiniai. Ultragarsinis tyrimas prieš reabilitacini gydymą atliktas penkiems $(62,5 \%)$ ligoniams, trims $(37,5 \%)$ ivertinti akies judinamieji tiesieji raumenys, dviems $(25 \%)$ nustatytas retrobulbarinių audinių paburkimas, vienam $(12,5 \%)$ - kraujosruva apie raumenis, vienam $(12,5 \%)$ - stiklakūnio drumstis. Po reabilitacinio gydymo ultragarsinis tyrimas kartotas tik vienam $(12,5 \%)$ ligoniui.

Apatinès sienelès lūžiai - jaunų žmonių problema, todèl ji turi būti aktyviai sprendžiama. Pagrindinis ligoniụ nusiskundimas dvejinimasis. Ultragarsinis tyrimas leidžia ỉvertinti pokyčius po traumos, parinkti gydymo būdą, reabilitacinio gydymo tikslingumą, gydymo veiksmingumą, todèl būtina ji i ivertinti. Reabilitacinis pooperacinis gydymas veiksmingas tada, kai ligoniui išlieka dvejinimasis, diagnozuota edema, formuojasi pooperacinis randas.

Raktažodžiai: reabilitacija, akiduobės apatinès sienelès lūžis, pooperacinės komplikacijos, ultragarsinis tyrimas. 